\title{
Rethinking macroeconomic theory before the next crisis
}

\author{
Marc Lavoie* \\ Centre d'Économie de Paris Nord, University of Paris 13, University of Sorbonne Paris Cité, France and \\ University of Ottawa, Canada
}

\begin{abstract}
Misguided economics policies relying on an unrealistic macroeconomic theory that denied the possibility of a crisis are at the origins of the global financial crisis. The goal of the present paper is to recall how the end of the Great Moderation has been interpreted by the advocates of mainstream economics, and how they have questioned their own macroeconomic theories as a consequence of what happened during and after the financial crisis. There is thus a need to reconsider most aspects of mainstream theory. In particular, the crisis has once more demonstrated that potential output is influenced by aggregate demand - a phenomenon associated with hysteresis, which also questions concepts such as the natural rate of interest and crowding-out effects.
\end{abstract}

Keywords: potential output, financial crisis, hysteresis, DSGE models

JEL codes: $E 31, E 51, E 52, E 58$

\section{INTRODUCTION}

While many countries throughout the world have faced severe financial crises over the last decades, and while the Japanese stagnation and the 1997 Asian financial crisis did induce some additional interest for the introduction of banking and finance into macroeconomic theory, it is only with the advent of the US subprime financial crisis that macroeconomic and monetary theories put forward by mainstream economists have started to be questioned. Still, there are at least two views about the role played by economic theory in generating the global financial crisis, which, depending on one's opinion, can be ascertained as having started at any of the three following times: when real-estate prices in the US started to decline in the summer of 2006; when interbank money markets first froze in Europe during the summer of 2007; or when it was announced that the Lehman Brothers investment bank declared bankruptcy on the

* The idea of this paper arose from a presentation that I was asked to make at the Jornadas Monetarias y Bancarias organized by the Banco Central de la República Argentina (BCRA) in Buenos Aires in November 2013. The ideas evolved as the result of another presentation that was made at the Grenoble Post-Keynesian Conference in December 2015. The present version of the paper was presented at the graduating ceremony of the students of the Erasmus Mundus Master program 'Economic Policies in the Age of Globalization' (EPOG) at the University of Paris 13 and at the annual meeting in Mulhouse of the Association française d'économie politique in the summer of 2016. I thank some of the participants for having encouraged me to transform the presentation into a paper. I also thank the two referees of the journal for their useful comments. This research has been sponsored by various grants from the Institute for New Economic Thinking (INET). 
15th of September 2008. If we take the earliest date, then we can say that the financial crisis and its aftermath have been going on for over a decade.

Heterodox authors were criticizing mainstream economic theory in all its incarnations long before the global financial crisis. My purpose in writing this paper is not to survey these heterodox criticisms, whose value has been reinforced with the advent of the crisis, nor to assess the impact of the crisis on the future of heterodox economics. ${ }^{1}$ Rather, the goal of the present paper is to briefly recall how the end of the Great Moderation - this 15 -year period of low inflation and low variance in real growth rates in the Western world - has been interpreted by the advocates of mainstream economics: this is mainly done in Section 2. The rest of the paper is devoted to a review of a number of key issues in macroeconomic theory, examining what seems to have been changed or been questioned as a consequence of what has happened during and after the financial crisis. As a result, Section 3 will be devoted to the concept of hysteresis, which seems to have been resurrected by mainstream economists. Section 4 will deal with a number of miscellaneous issues, in particular the shape of the aggregate demand curve and the lack of a relationship between interest rates and public debt or deficit ratios. I will conclude in Section 5 with broad brush-strokes about what ought to disappear and what might disappear from macroeconomic theory. Many others, such as Stiglitz $(2011 ; 2015)$ and Mendoza Bellido (2013) have done an excellent job in pursuing this kind of exercise. Here I offer my idiosyncratic thoughts, starting with the reaction of economists to the crisis.

\section{REACTIONS TO THE CRISIS}

It is well known that, just before the crisis, mainstream economists were bragging about how good their macroeconomic theories and policies had become. Just as the crisis was in the making, Olivier Blanchard (2008, pp. 2 and 26), the chief economist at the International Monetary Fund (IMF), claimed that 'the state of macro is good ... . Macroeconomics is going through a period of great progress and excitement'. A few years before, Robert Lucas (2003, p. 1), the gravedigger of the Keynesian revolution and the advocate of the delusion that formal microfoundations were a sufficient support for good macroeconomics, stated that supply-led economics was all that one should care for, with aggregate demand phenomena being well tamed: 'Macroeconomics in this original sense has succeeded: Its central problem of depression prevention has been solved, for all practical purposes, and has in fact been solved for many decades ... . The potential for welfare gains from better long-run, supply-side policies exceeds by far the potential from further improvements in short-run demand management' (emphasis in the original). Has anything changed since the advent of the crisis?

The first view about economic theory and the global financial crisis is that economic theory has nothing to do with it. This view is most entertained by economists who believe that the government should refrain from intervening in the economy and who believe that unfettered markets remove any imbalances and will keep the economy at full-employment equilibrium. However, even among people who hold more reasonable views, there is a belief that very little in economic theory or in economic policy needs

1. A long list of papers and books could be provided; for instance, just to offer a small sample, the book by Tom Palley (2012), or the papers by Heinz Kurz (2010) and Robert Blecker (2016). I have written on this topic in a number of places (Lavoie 2010a; 2012; 2012/2013; 2015a; 2015b; 2016). 
to be changed. This view has been propounded by Olivier Blanchard, when he argued that 'the crisis was not triggered primarily by macroeconomic policy ... . In many ways, the general policy framework should remain the same' (Blanchard et al. 2010, p. 16). Similarly, the former Chairman of the Federal Reserve, Ben Bernanke (2010), argued that 'calls for a radical reworking of the field go too far' (p. 2), insisting that 'the recent financial crisis was more a failure of economic engineering and economic management' (p. 3), while shortcomings of 'economic science, in contrast, were for the most part less central to the crisis' (p. 4). Indeed several mainstream economists, as recalled by Mendoza Bellido (2013), believe that mainstream macroeconomics can be easily repaired from within, or that the required modifications already existed before the crisis but were ignored.

Several mainstream economists still believe that 'any interesting model must be a dynamic stochastic general equilibrium model. From this perspective, there is no other game in town .... If you have an interesting and coherent story to tell, you can tell it in a DSGE [dynamic stochastic general equilibrium] model. If you cannot, your story is incoherent' (V.V. Chari, as quoted by Garcia Duarte 2012, p. 220). ${ }^{2}$ Similarly, not very long ago, Blanchard (2014, p. 31) was affirming that the solution to previous mistakes was that 'DSGE models should be expanded to better recognize the role of the financial system'. It is hard to see how conceiving of the financial system as frictions to the real economy can help in understanding macroeconomics. Simon Wren-Lewis (2016, p. 33) is adamant that the methodology proposed by what he calls the New Classical Counter Revolution, enclosed into DSGE and New Keynesian models, is a worthy one, and that as a consequence "the microfoundations methodology is entrenched ... so it is unlikely that its practitioners will down tools and start afresh'. Wren-Lewis further claims that 'the methodology is progressive', and believes that 'researchers are devoting a good deal of time to examining real/financial interactions' (ibid., p. 30), so that all is well as long as Keynesian results are not excluded by assumption and can be recovered from the simulations. This, it would seem, is close to Blanchard's (2016, p. 1) latest position, who sees 'the DSGE models as seriously flawed', still believing however that 'they are eminently improvable and central to the future of macroeconomics'.

The second view about economic theory and the global financial crisis is that economic theory was indeed a cause of the crisis. This view is very much entertained by left-wing heterodox economists in general, for instance Heinz Kurz (2010) and Thomas Palley (2012), but it can also be found among neo-Austrian economists and among orthodox economists, or at least among those that I like to characterize as dissident orthodox economists. Neo-Austrian economists, in particular those working at the Bank for International Settlements (BIS), were quite critical of the New Consensus among mainstream economists even before the advent of the subprime financial crisis. For instance Borio and White (2004) argued early on that the move towards more liberalized financial markets and the increased reliance on market evaluations have increased the inherent procyclical tendencies of asset prices and of the banking system, making it more vulnerable to boom and bust cycles, thus contradicting the apparent success of inflation-targeting policies and creating large imbalances and credit swings. After the crisis, White (2009, pp. 1-2) claimed that 'the prevailing paradigm of macroeconomics allows no

2. I heard Michael Kumhoff, from the IMF, make a very similar statement at the 'State of Economics after the Crisis' FMM Berlin conference in October 2012, despite the fact that obviously he is ready to entertain some eclectic views. Thus, if even dissident orthodox economists argue that the DSGE model is a must, there isn't much room left for alternatives!. 
room for crises of the sort we are experiencing', adding that 'the recent crisis has demonstrated the inadequacy of models based on the assumption of rational expectations', and concluding that 'the crisis provides evidence that the simplifying assumptions on which much of modern macroeconomics is based were not useful in explaining real-world developments'.

The strongest indictment of orthodox theory from the orthodox side was perhaps made by Willem Buiter, a former member of the Monetary Policy Committee of the Bank of England, and admittedly an early critic of the hypothesis of rational expectations. In a now famous blog, Buiter (2009) wrote that 'the typical graduate macroeconomics and monetary economics training received at Anglo-American universities during the past 30 years or so may have set back by decades serious investigations of aggregate economic behaviour and economic policy-relevant understanding'. Buiter (ibid.) referred to models based on New Classical and New Keynesian economics, and thus to DSGE-type models, as the kind of modelling that offers no clues as to "how the economy works - let alone how the economy works during times of stress and financial instability'. Robert Solow, who is sometimes considered as the father of DSGE models because of his famous 1956 neoclassical growth model, has also repudiated DSGE models, saying that its foundations were 'dumb and dumber macroeconomics' (Solow 2003), and that adding realistic frictions did not make these models any more plausible (Solow 2008, p. 244). ${ }^{3}$ Not unexpectedly, Joseph Stiglitz (2015, p. 43) has also been an advocate of the second view, arguing that macroeconomics has done poorly over the years, as 'the models/theories that guided policy were not just innocent bystanders in the crisis that unfolded beginning in 2008 . They were critical in the creation of the crisis and in the inadequate responses to it'.

Critics of DSGE models do not only include heterodox economists and past recipients of the Nobel prize. In an endorsement of Buiter's claim above, Paul Romer (2016), the new chief economist at the World Bank, provoked quite a stir when he wrote that he had 'observed more than three decades of intellectual regress' in macroeconomics (p. 1), adding that it had turned into 'pseudoscience', targeting explicitly the work of Lucas and that of the New Classical economists. ${ }^{4}$ Similarly, Hope and Soskice (2016, p. 218) write that 'despite its several associated Nobel prizewinners, and the fact that it is still staple teaching in many graduate schools, RBC [real-business cycle theory] - with its roots in Chicago and the Midwest - is regarded by many macroeconomists (including many of those in universities on the 'two coasts' such as Harvard, Princeton, MIT, NYU, Berkeley, and Stanford) as aesthetically beautiful but mad' (emphasis added). One presumes that the main reason is that, as recalled by Stiglitz (2015, p. 24), RBC theory 'took the (seemingly absurd) view that what was

3. This critique from Solow is ironically very similar to that made by Kaldor in 1966 and 1972 when he was arguing that neoclassical economics was based on unrealistic foundations and that removing the scaffolding of unrealistic assumptions with bits of realisticness would not make the theory any more solid. Goodhart (2009, p. 353) makes an assessment of the DSGE approach which is similar to Solow's when he says that 'like astronomers seeking to maintain the Ptolomaic system, they are trying to add refinements to make it consistent with the data'.

4. Some heterodox economists seem to be rather enthusiastic about Romer's denunciation, but they seem to forget that it was the same Romer (1999, p. 299) who wrote that 'Solow and Samuelson had to engage in vicious trench warfare about this time with Cambridge, England, to make the world safe for those of us who wanted to use the concept of a production function', thus being seemingly unaware that Samuelson had conceded defeat to Cambridge, England or that the output elasticities are artefacts. Romer $(2015$, p. 89$)$ has recently repeated this kind of misleading statement, as recalled by Lavoie and Seccareccia (2015). 
widely viewed as unemployment was actually just leisure', thus having to explain the 'wide fluctuations in the demand for leisure'.

Are New Keynesian DSGE models any better? Hope and Soskice (2016, p. 218) give them high marks for taking on board what they think are sensible assumptions, that is, the assumption that 'companies everywhere operate under conditions of imperfect competition' and that they set prices at discrete intervals of time (the Calvo pricing hypothesis). But Hope and Soskice object to the rest of the New Keynesian assumptions, borrowed from the New Classical economists. As a consequence, 'the result has increasingly been macro models of great complexity that bear little relation to reality', Hope and Soskice (2016, pp. 218-219) add that 'the dysfunctional driver of evolutionary progress in New Keynesian economics has been the internal theoretical standards of the academic profession, rather than a concern to understand how the macroeconomy works'. They suggest as an alternative what they call realistic modern macroeconomics, which relies on what they consider to be the improvements provided by New Keynesian economics, stepping away however 'from the (unrealistic) assumption that all actors are fully forward-looking and rational' (ibid., p. 219). In effect, they reject rational expectations. ${ }^{5}$

The central line of defence of orthodox economists is that the criticisms of orthodox macroeconomic theory are misdirected because, as put forth by Thomas Sargent, its models 'were designed to describe aggregate economic fluctuations during normal times ... not during financial crises and market breakdowns' (Rolnick 2010). It is claimed that the main tool of central bankers, the DSGE model, was doing very well as long as the American or European economies were moving along the lines of the Great Moderation. There seems to be a consensus about the limited range of application of DSGE models. Charles Goodhart (2009, p. 352) writes that these models 'were, by construction, fair weather models only'. Similarly, for Bernanke (2010, p. 17), 'the standard models were designed for these non-crisis periods'. Blanchard (2014, p. 28) has blamed this on the kind of techniques that were used by mainstream economists, claiming that these "were best suited to a worldwide view in which economic fluctuations occurred but were regular, and essentially self-correcting'. Blanchard (ibid., p. 29) has also claimed that everyone knew that these models were useless when the conditions of the Great Moderation did not hold: "we all knew that there were "dark corners" - situations in which the economy could badly malfunction. But we thought we were far away from those corners, and could for the most part ignore them'. ${ }^{6}$ Blanchard (ibid.) still believed then that with improved models the economy will stay away from what he calls 'the dark corners', where mainstream models can provide no light. But this sounds like wishful thinking. There is a need for theories or models that take these dark corners as genuine components or likely possibilities.

Still it seems that some economists are saying tout et son contraire. Take for instance the case of David Colander, who is usually deemed to be a mainstream economist by heterodox authors while being perceived as a key voice of the heterodoxy by the mainstream. Colander has been a long-time advocate of what he called the post-Walrasian

5. Hope and Soskice (2016) present Carlin and Soskice (2015) as the textbook exemplar of this realistic modern macroeconomics. See Lavoie (2015c) for a less enthusiastic assessment of their book.

6. This is reminiscent of Lucas (1981, p. 224) who, when asked about how fundamental or radical uncertainty, by contrast with risk, could be taken into account, wrote that radical uncertainty had to be assumed away because 'in cases of uncertainty, economic reasoning will be of no value'. 
approach, also presented as the complexity approach to macroeconomics. In 2006 he published a book, the subtitle of which was Beyond the DSGE Model. Nevertheless, in a paper presumably written before the Lehman Brothers default, he was telling us that the DGSE model 'is well founded, scientific, and potentially more progressive', highlighting the 'intellectual coherence and mathematical elegance of DSGE models', and concluding that 'thanks to DSGE we know more than we used to about the economy', all this despite having noted a page before that the DSGE standard 'involves idealizing to a world we can fully understand in the hope that understanding this simplified world will help us better understand our own' (Colander and Rothschild 2009, pp. 126-127). A year later, Colander (2010, p. 420) offered a rather different assessment of DSGE models, saying that the primary, and 'highly problematic', reason for their success was 'that [they were] appropriately micro-founded'. The new Colander (ibid., p. 424) added that before the financial crisis economists 'were well aware of the model's serious limitations in describing the real-world macro economy' - a claim similar to that made by Blanchard, Bernanke and Sargent, as recalled earlier.

There has also been a reversal regarding the worthiness of some concepts. For instance, there is now a great deal of renewed interest in the notion of hysteresis, a concept which mainstream economists such as Blanchard and Summers introduced in discussions about unemployment in the early 1980s but which had nearly completely vanished with the apparent success of the Great Moderation, only to reappear during the prolonged aftermath of the 2008 financial crisis. Some could even say that Blanchard has recanted from his previous stand on the state of macroeconomics. In a recent interview in the IMF Survey Magazine, he made the following statement, that seems to open the door to alternative views and in particular to views endorsed by long-time advocates of post-Keynesian economics:

As a result of the crisis, a hundred intellectual flowers are blooming. Some are very old flowers: Hyman Minsky's financial instability hypothesis. Kaldorian models of growth and inequality. Some propositions that would have been considered anathema in the past are being proposed by 'serious' economists: For example, monetary financing of the fiscal deficit. Some fundamental assumptions are being challenged, for example the clean separation between cycles and trends: Hysteresis is making a comeback. This is all for the best. (Blanchard 2015) ${ }^{7}$

In this interview Blanchard points out that the global financial crisis has made a lot of people realize that what had become the established or fashionable theoretic approach in economics was not necessarily the best, and that it was time to go back to some of the ideas and models that had been set aside or abandoned in the past. Buiter (2009), in the article referred to earlier, had mentioned as possible alternatives the works of behavioural economists, as well as those of Hyman Minsky, Stiglitz and Tobin. Alan Blinder (2014, pp. 6-8), a former central banker, wrote that two of the lessons to be learned from the financial crisis were that 'Minsky was basically right' and 'self-regulation is oxymoronic'. As to Paul Krugman, it is well known that he has repeatedly affirmed that the old IS-LM Keynesian model provided more insights than any of the fashionable macro models based on neoclassical microfoundations and the rational expectations hypothesis to understand what has happened to major macro aggregates over the last seven years, although a return to the IS-LM model is probably not the direction that most heterodox economists would like to pursue.

7. Similarly, Bill White (2009), the former chief economist at the BIS, and currently the chairman of the Economic Development and Review Committee at the OECD in Paris, refers his readers to the works of Fisher, Minsky, Foley, Akerlof and Soros. 


\section{THE REAPPEARANCE OF THE CONCEPT OF HYSTERESIS}

\subsection{Mainstream views}

As noted by Blanchard in the previous indented quote, there is a return of the concept of hysteresis and the possible rejection of models based on the assumption of stationarity around a trend. As Blanchard (2014, p. 28) points out elsewhere, mainstream macroeconomists saw 'the economy as roughly linear, constantly subject to different shocks, constantly fluctuating, but naturally returning to its steady state over time', either through market self-correcting mechanisms or through the actions of an all-powerful central bank. In neoclassical CGE models, full employment is assumed, and the effects on output can only be achieved by efficiency or productivity gains that arise from specialization or the removal of what the modellers consider to be microeconomic distortions. In DSGE models, it is assumed that the economy will necessarily come back to its potential output, which is essentially determined by the supply of labour, set by demographics and the level of the real wage. If any change in the rate of employment occurs, it can only arise as a consequence of a short-term deviation that will be wiped out over the long run. In those models, just as in the neoclassical computable general equilibrium (CGE) models, output and employment can only be improved by the removal of rigidities and distortions, where relative prices once again play the essential role. Whether discussing neoclassical CGE or DSGE models, increases in employment will be driven through the labour supply function, with higher real wages inducing more consumers to drop their leisure time and increase the time they wish to devote to work.

In the DSGE model, the economy always goes back to its NAIRU (non-accelerating inflation rate of unemployment) or NAICU (non-accelerating inflation capacity utilization), which is entirely determined by supply-side factors. Whether we are talking of neoclassical CGE static models or of the dynamic stochastic equilibrium models does not matter: these mainstream models in general do not take into account that the new equilibrium resulting from some change or shock will be influenced by what occurs during the transition from one equilibrium to the next. In other words, these models assume away path-dependence and hysteresis. They assume away the possibility that demandled factors will have an impact on the long-run equilibrium, for instance the long-run value of potential output or the long-run value of the natural rate of unemployment. They assume away the possibility that demand-led factors can change the slope of the trend growth rate of potential output over the long run.

Laurence Ball (2014, p. 149) summarizes this feature of mainstream models in the following way:

A fall in aggregate demand causes a recession in which output drops below potential output the normal level of production given the economy's resources and technology. This effect is temporary, however. A recession is followed by a recovery period in which output returns to potential, and potential itself is not affected significantly by the recession.

This is illustrated in Figure 1. As recognized by Paul Krugman (2009), at least until the beginnings of the global financial crisis, "self-described New Keynesian economists weren't immune to the charms of rational individuals and perfect markets. They tried to keep their deviations from neoclassical orthodoxy as limited as possible'. The standard DSGE model, designed by New Keynesian economists, has illustrated 'how Panglossian even New Keynesian economics had become' (ibid.).

More recently, the global financial crisis has clearly illustrated that quantity effects generated by demand-led factors have had a much greater role to play than price 


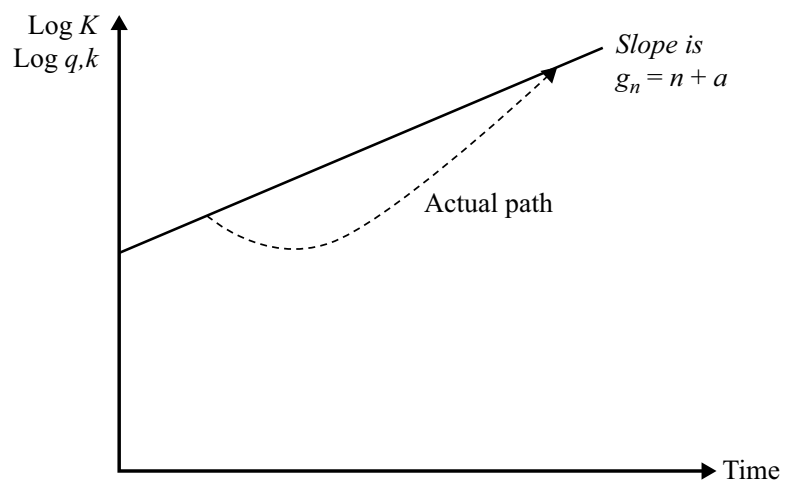

Figure 1 The mainstream view (New Consensus, DSGE)

effects coming from supply-side factors. This has been pointed out even by some authors, such as Lawrence Summers (2014), who in the past had succumbed to the sirens of supply-led models. Summers, as reported by Laurence Ball (2014, p. 149), went so far as to argue in a conference on full employment that 'this financial crisis has confirmed the doctrine of hysteresis more strongly than anyone might have supposed'. ${ }^{8}$ Ball (ibid.) has studied the impact on potential output of the global financial crisis for a sample of 23 countries. His conclusion is that 'most countries have experienced strong hysteresis effects: shortfalls of actual output from pre-recession trends have reduced potential output almost one-for one' (ibid., p. 149). This, he says, has occurred through a reduction in capital accumulation, a lower labour force participation rate, and a slow-down in the growth rate of productivity. I will briefly come back on this third cause in the text below.

But these hysteresis effects have not only arisen as a consequence of the recent global financial crisis. They have arisen in a majority of previous recessions. Blanchard et al. (2015), in a study of over 120 recessions, assess that more than two-thirds of them have led to a permanent gap between the previously estimated potential output and the after-recession estimate. In one-third of the recessions, this gap was actually increasing through time, meaning that the growth rate of potential output had actually declined - a result which is consistent with the earlier work of León-Ledesma and Thirlwall (2002), as we shall see below. Summers (2015, p. 8) has summarized this by saying that 'reversion back to trend is actually less common than evidence that the recession not only reduced the level of GDP, but reduces the trend rate of growth of GDP, what Larry Ball has referred to as super hysteresis'. Hysteresis, as it used to be mostly understood by some eclectic New Keynesian authors, and super hysteresis, as it was mostly advocated by post-Keynesian authors, are illustrated in Figures 2 and 3 respectively. In Figure 2 the economy returns to its previous long-run growth rate, but the level of output does not go back to what it would have been without the recession. In Figure 3, the economy never goes back to its previous long-run growth rate the case of super hysteresis.

8. As an example of this, Vítor Constâncio (2015), from the ECB, has recently pointed out that ' $[\mathrm{a}[\mathrm{t}$ the aggregate level, the euro area output is now 20 percent below the level it would have achieved had the trend growth in the previous 15 years continued after $2007 \ldots$. The crisis left a permanent economic loss with broad scars in our societies'. 


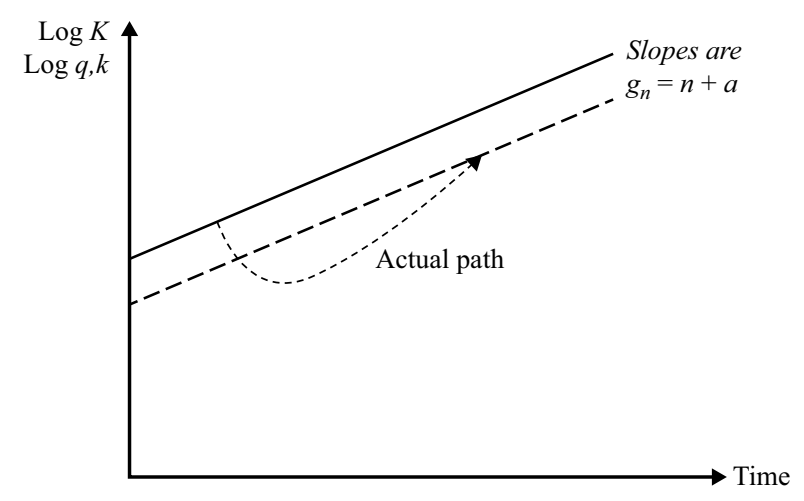

Figure 2 Hysteresis

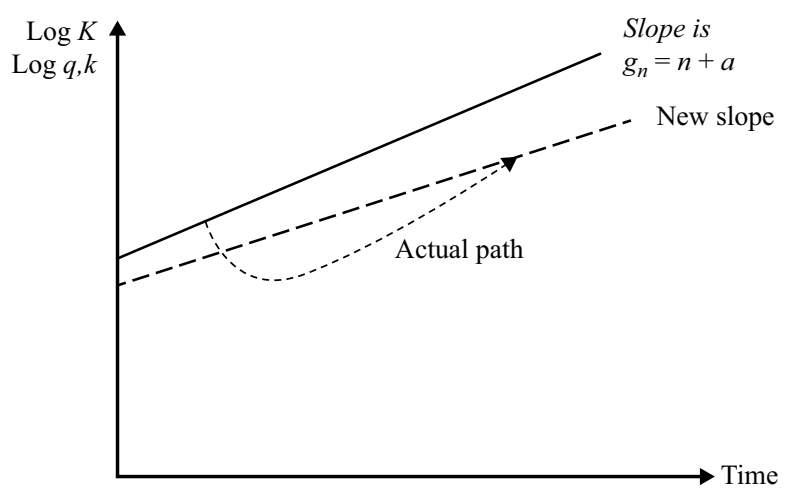

Figure 3 Super hysteresis

In other words, as long as we accept that recessions are mostly caused by elements related to the demand side, and not to unexpected drops in productivity as argued by advocates of the real-business cycle theory, aggregate demand does have a feedback effect on the long-run supply side. As Stiglitz (2015, p. 35) forcefully argues, 'the problem is lack of aggregate demand'. Thus, to provide a compelling analysis of what is going on, we need models that are demand-led, possibly with the incorporation of some supply-side elements that will allow us to assess the possible effects on potential output.

\subsection{Post-Keynesian views}

There has always been a tradition in economics that kept rejecting the supply-led approach. It is well-known that the Keynesian tradition has put the emphasis on demand-led factors. This does not mean that supply factors are totally ignored. What it means instead, as implied by the following two statements from wellknown Cambridge authors, is that the natural rate of growth is heavily influenced by the growth rate of demand. 
But at the same time technical progress is being speeded up to keep up with accumulation. The rate of technical progress is not a natural phenomenon that falls like the gentle rain from heaven. When there is an economic motive for raising output per man the entrepreneurs seek out inventions and improvements. Even more important than speeding up discoveries is the speeding up of the rate at which innovations are diffused. When entrepreneurs find themselves in a situation where potential markets are expanding but labour hard to find, they have every motive to increase productivity. (Robinson 1956, p. 96)

The stronger the urge to expand ... the greater are the stresses and strains to which the economy becomes exposed; and the greater are the incentives to overcome physical limitations on production by the introduction of new techniques. Technical progress is therefore likely to be greatest in those societies where the desired rate of expansion of productive capacity ... tends to exceed most the expansion of the labour force (which, as we have seen, is itself stimulated, though only up to certain limits, by the growth in production). (Kaldor 1960, p. 237)

Thus, there is a long-standing tradition in post-Keynesian economics that contends that the natural rate of growth is not a strong attractor of actual growth rates. As Mark Setterfield (2002, p. 5) - a long-time advocate of hysteresis models and hysteresis effects - points out, 'the natural rate of growth is ultimately endogenous to the demand-determined actual rate of growth'. For instance, in an interesting empirical study that was completed before the subprime financial crisis, Leon-Ledesma and Thirlwall (2002) have shown that the natural rate of growth, which is at the heart of supply-side analyses, is in fact endogenous to the growth rate of actual output, providing evidence that the natural rate of growth rises in booms and falls in recessions. As they say (ibid., p. 452), 'growth creates its own resources in the form of increased labour force availability and higher productivity of the labour force'. Their results, at which they arrive by finding the GDP growth rate that leaves constant the rate of unemployment, have been confirmed by a number of other empirical studies, using the same methodology, for other regions of the world. These studies have yielded similar results for North America, Latin America and Asia.

As an aside, it should be mentioned that most mainstream economists and policymakers interpret hysteresis as being something that only occurs on the downward side. A financial crisis or some other catastrophic shock is presumed to have bad hysteretic or super-hysteretic effects on the economy, essentially through the labour market, as unemployed workers are said to be losing their working skills. ${ }^{9}$ But it is not contemplated that the phenomenon of hysteresis may also apply on the upward side, say because rising government expenditures or a credit boom generate an increase in the so-called natural rate of growth. This is to be contrasted with the post-Keynesian view, as presented in the above paragraphs, and as reflected in the numerous empirical works on the Kaldor-Verdoorn effect, whereby fast growth rates in manufacturing or more generally in GDP lead to an acceleration in the growth rate of labour productivity. For post-Keynesians, slower and faster growth in aggregate demand will induce effects on the possible growth rates of supply. In the mainstream view, these effects

9. As a deputy-governor at the Bank of Canada says: 'The decline in the participation rate of young and prime age workers reflects the cyclical effects of a weak job market. But these cyclical effects could become structural. After a long search, if you don't think you are going to find a job, at some point, you become discouraged and you stop looking. The longer you stay out of the labour force, the more likely it is that your skills have deteriorated and your attachment to the job market has weakened. This is what economists mean when we talk about hysteresis' (Wilkins 2014, p. 3). 
only occur on the downward side, if at all, since it is sometimes argued that it is a fall in the growth rate of potential output that has generated the observed fall in the growth rate of aggregate demand.

\subsection{Fallouts}

An interesting feature of the work of Blanchard et al. (2015, p. 14) is that they recover the same hysteresis and super-hysteresis effects when recessions are intended and induced by restrictive anti-inflation monetary policy - a clear case of recessions caused by reductions in aggregate demand. In other words, while an observer trained in New Classical economics could possibly argue that both the initial recession and the fall in future potential output had the same cause - a slowdown in productivity growth - the fact that recessions induced by restrictive monetary policy also lead to reductions in middle-run or long-run potential output shows that demand shocks also have a long-run negative impact. This has all kinds of interesting policy consequences.

First, obviously, if potential output depends on demand, then it must be that the NAIRU and the SIRCU (the steady-inflation rate of capacity utilization) are also influenced by demand factors. Before the crisis, several authors had provided empirical evidence that the NAIRU hypothesis had been falsified many times over and that it should be abandoned (Storm and Naastepad 2007; Mitchell and Muysken 2008; Vergeer and Kleinknecht 2010/2011). There were also some signs that institutions like the OECD - the champion of labour flexibility - was (sometimes) backtracking on its claims and on its systematic calls for labour market reforms. The crisis has provided more credence to these studies that reject the NAIRU. Before the crisis, it was believed that unemployment rates in the US were lower than elsewhere because their labour market was more flexible. When unemployment rates in the US started to exceed those of most European countries it became evident that unemployment rates were high because aggregate demand at the time was low. There is no such thing as a NAIRU, as became obvious even before the crisis. Indeed, this is the conclusion of Tom Stanley (2004, p. 65), who through two metaregression studies concludes that the NAIRU hypothesis has been empirically and definitely refuted. Still, within the context of European policies, calls for labour reform - a euphemism for lower real wages and less job security - continue unabated.

A second consequence of the results obtained by Blanchard et al. (2015) is that recessions imposed on purpose by the monetary authorities in their attempt to reduce inflation rates or in pre-emptive strikes against inflation are likely to have long-run negative effects on economic activity. It was always claimed by central bankers that restrictive monetary policies were good for the economy because by producing short-term recessions they would generate lower inflation rates and more efficiency, thus achieving higher output per capita in the long run. Short-run pain was needed to achieve long-term bliss. The only question was whether the central bank could devise means, such as inflation targeting, by which the inflicted short-term pain could be reduced (how the sacrifice ratio could be somewhat reduced). It was always denied that short-term recessions engineered by central banks could generate lower long-run potential outputs. Central bankers now start to recognize that imposing low inflation may inflict long-run and permanent costs; in other words, they admit the possibility of hysteresis.

Furthermore, central bankers have been unable, after more than 30 years of intensive search, to provide any compelling evidence that low inflation is conducive to high productivity growth, in contrast to what was earlier asserted when anti-inflation 
policies were put in place as a follow-up to and replacement of monetarist policies. The assertion was based on the special case of the 1970s when high inflation rates were associated with a slow-down in productivity growth, but the negative relationship was never recovered afterwards. And of course, the subprime financial crisis has provided the clearest of demonstration that low inflation rates could not guarantee financial stability, as was once hoped for.

An interesting additional fallout from this rediscovery of hysteresis effects is related to the impact that fiscal expansion (or contraction) may have on economic activity in the medium or long run. This was pointed out by DeLong and Summers (2012) when they argued that, in a recession, an increase in government expenditure was likely to lead to a reduction in the debt-to-GDP ratio in subsequent periods, despite raising the ratio in the current period. This paradoxical result is attributed to hysteresis effects. ${ }^{10}$ As any post-Keynesian economist would tend to argue, lower GDP leads to less investment, and hence leads to less output capacity, which is likely to affect the level of aggregate demand which is likely to be judged appropriate by the monetary authorities. This further illustrates the importance of incorporating demand-led path dependence.

\section{THE SHAPE OF THE AGGREGATE DEMAND CURVE AND THE NATURAL RATE OF INTEREST}

Several other beliefs, that one would have thought were well entrenched in mainstream macroeconomics, have been questioned as a consequence of the financial crisis and its aftermath. One of them is the belief that the aggregate demand curve has the standard negative slope. The desperate efforts of central bankers to stop prices from falling has clearly shown that central bankers, for all practical purposes, do not hold to the standard view that more flexibility in wages and prices is conducive to a better performance. The textbook view is illustrated with the help of Figure 4, where Pigou's effects generate the downward slope of the aggregate demand curve. In a self-adjusting system, with no rigidities, a recession should induce a fall in wages and prices. A reduction in the wage rate leads to a rightward shift of the aggregate supply curve (from $\mathrm{AS}_{1}$ to $\mathrm{AS}_{2}$ ), and thus, with the standard negatively sloped aggregate demand curve, this ought to lead to an increase in real output, here from $Y_{1}$ to $Y_{2}$. Why then would central banks pursue all kinds of non-conventional measures to stop wages and prices from falling when a recession occurs?

Obviously, as shown in Figure 5, if the aggregate demand curve is upward-sloping instead of downward-sloping, then the actions of central bankers - putting aside the fact that several central banks are committed to inflation-targeting and hence aim at low inflation rates - are much easier to understand. In this case, a fall in wages and prices also shifts the aggregate supply to the right, but this time the lower wages and prices induce a decrease in the level of real output, which falls from $Y_{1}$ to $Y_{2}$ in

10. The relevance of hysteresis and super-hysteresis effects was at the heart of the controversy between Gerald Friedman (2016a; 2016b) - an economist from the University of Massachusetts in Amherst - and Christina and David Romer (2016) regarding the estimated effects of the economic program of the 2016 Democrat presidential candidate Bernie Sanders. To his dismay, Friedman discovered that the Kaldor-Verdoorn hysteresis effects that he had assumed in his estimates were not part of standard modelling, that is, the kind of models that are used by the Council of Economic Advisers. 


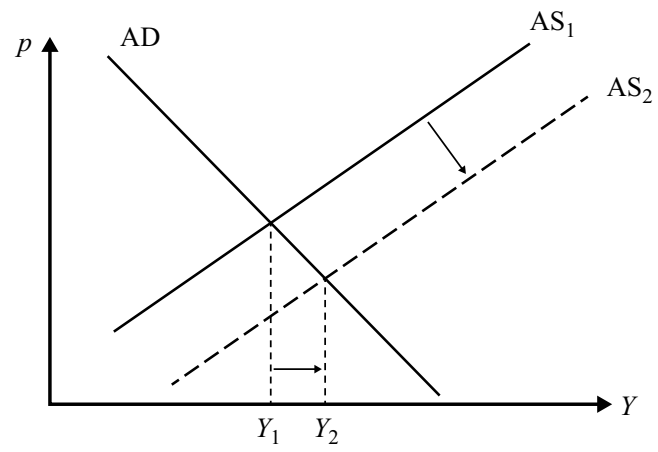

Figure 4 The effect of falling wages in the mainstream view

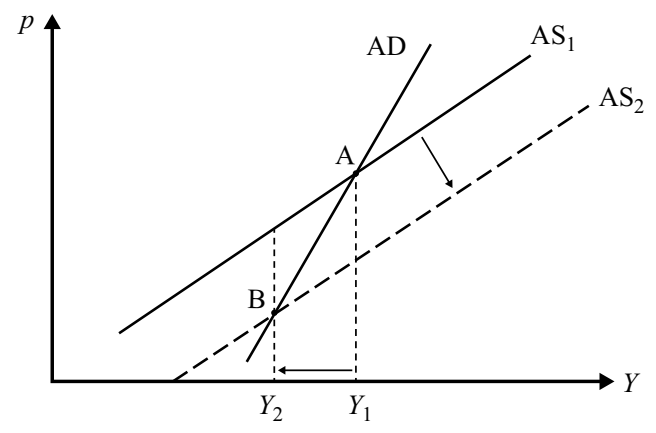

Figure 5 The effect of falling wages in the Fisher-Tobin-Minsky view

Figure 5, as the equilibrium point moves from $\mathrm{A}$ to $\mathrm{B}$. This is what is called here the Fisher-Tobin-Minsky effect, in honour of the three economists who have emphasized the possibility of debt deflation - as did Kalecki when responding to the wealth effects proposed by Pigou as a response to Keynes's unemployment equilibrium. The downward flexibility in wages and prices does not engineer a recovery of output. Instead, it engineers mounting problems for those households and firms which have large liabilities, and leads to debt defaults and bankruptcies, as well as the destruction of output capacity. ${ }^{11}$

Modern macroeconomic theory, based on the New Consensus, relies on a presentation that highlights the rate of price inflation rather than the price level. In the not-so-distant past, the limits to monetary policy were being attributed to rigidities in real wages. If the rate of inflation got close to or reached zero, it was argued that there was no room for real wages to decline in a down-turn, because nominal wages were downwardly rigid and were unlikely to fall. Inflation was needed to 'grease the wheels' of the labour market. With inflation at or close to zero, nominal wages and hence real wages would not fall when faced with a decline in nominal aggregate demand, and as a consequence firms would be forced to lay off workers, unemployment would rise, and real GDP would fall. The economy would need wage deflation to achieve potential output.

11. A list of references regarding the Fisher-Tobin-Minsky effect can be found in Lavoie (2010b). 
The downward rigidity in nominal wages close to zero price inflation has now been replaced by the downward rigidity of nominal interest rates in the pantheon of neoclassical explanations of unemployment and economic stagnation. This is the highly heralded zero lower bound on nominal interest rates, or what Krugman has called, erroneously, the liquidity trap. The aggregate demand curve with the inflation rate on the vertical axis, or what some prefer to call the 'inflation-output' relationship, instead of being downward-sloping could become upward-sloping and hence generate perverse results. With nominal interest rates at their zero lower bound and once more with inflation rates at or near zero, real interest rates cannot be made to be negative enough to achieve the real rate of interest that would be needed to bring back the economy to potential output or full employment. The nominal interest rate would need to be negative for the equilibrium real interest rate to be achieved. This New Consensus story put forward by New Keynesians and Krugman in particular, which heterodox authors and Stiglitz (2015, pp. 39-43) do not buy, is no different from the one told nearly 70 years ago by Don Patinkin (1948) in the American Economic Review: the investment and the full-employment saving functions were said to equate each other at a negative interest rate. As the French say, 'plus ça change, plus c'est pareil'!

Normally, all else being equal, the central bank would like to reduce the real rate of interest whenever the inflation rate and autonomous demand relative to potential output get lower. This generates the standard negative slope of the inflation-output curve. However, at some deflation rate, it is no longer possible to reduce real interest rates due to the fact that nominal interest rates cannot fall below zero (or so we all thought!). At that point, the inflation-output curve becomes positively sloped (as does the AD curve in Figure 5), as larger deflation rates (in absolute terms) lead to higher (rather than lower) real interest rates and hence to a decrease in the interest-elastic portion of spending.

This explains why New Keynesian economists advocate policies, such as quantitative easing, that could stop inflation expectations from falling below the inflation target, so as to avoid making things worse. And since these policies have proven to be largely ineffective, it explains why New Keynesians are once more considering the relevance of expansionary fiscal policies that would induce an increase in real demand. But why is the economy away from potential output in the first place? As recalled by Eckhard Hein (2016), the more eclectic mainstream authors invoke the long-term effects of the financial crisis on aggregate demand; the more mainstream ones blame long-term supplyside effects that have reduced potential output or the growth rate of potential output. Arguments invoking excess saving and deleveraging have also been put forward. Whatever is the case, there is now a near consensus among mainstream authors that the real natural rate of interest is lower than it used to be, which makes it harder to achieve it and hence makes it harder to achieve potential output when the rate of inflation is around zero or negative. In the case where aggregate demand is below potential output, it is argued that the temporary neutral interest rate which is necessary to bring the economy back towards potential output is then below the long-term natural rate and hence is even harder to achieve through conventional monetary policies.

All this is rather confusing. Before the crisis, the long-term rate of interest on corporate bonds or on government bonds was deemed to be a good proxy of the (nominal) natural rate of interest. It was said that a central bank should align its administratively determined short-term interest rate to this long-term rate. During the crisis, the longterm interest rate, for instance the Baa corporate rate, shot up, as a consequence of uncertainty and risk premia; but at the same time a number of economists were arguing that the natural rate of interest had become negative. There was a contradiction. From a 
pedagogical point of view, it is clear that we can no longer speak of the rate of interest. Also, what is the meaning of the natural rate of interest in a world where the NAIRU and potential output are being determined by aggregate demand?

In the past, mainstream economists kept claiming that public deficits and public debts led to overly high interest rates, despite the fact that past econometric evidence relating public deficits or public debt to high interest rates had always been very weak. During the crisis, several countries have encountered large deficits and large public debt-to-GDP ratios while both their short-term and long-term interest rates have remained low and in fact have gone down, as was the case in Japan, the USA and the UK. The existence of a general positive relationship between public deficit or public debt-to-GDP ratios and nominal or real interest rates (found in the IS-LM model or in the New Consensus model), which had always relied on poor empirical evidence anyway, must thus be relegated to the dustbin.

Still, some countries (of the eurozone) have suffered from high interest rates during the crisis, when faced with rising debt and large current-account deficits. These high interest rates arose mainly from the financial market fears of sovereign default. There is now a growing recognition that countries which have their own currency and their own central bank, and which borrow in their own currency, run no risk of insolvency and of default. This has now been recognized by mainstream authors such as Krugman and Paul De Grauwe, who, prior to the crisis, failed to understand the peculiar and faulty set-up of the common currency of the eurozone, whereas heterodox authors such as Godley (1992), Palley (1997), Parguez (1999) and Simonazzi and Vianello (1999) predicted in the 1990s that the eurozone countries would be at the mercy of the whims of the financial markets. Indeed, ever since the European Central Bank (ECB) announced that it would do anything in its power to control interest rates, these interest rates have gone back down (except in Greece), and have reached ever lower levels.

The eurozone crisis has also led to a reconsideration of a major tenet of mainstream economic policy, that is, the belief that as soon as some negative shock has induced the appearance of a fiscal deficit, the government should quickly engage in a consolidation program designed to remove the deficit and possibly to reduce the public debt-to-GDP ratio. Some researchers at the IMF now argue that while public debt imposes a deadweight loss on the economy, when there is little risk of a speculative attack against sovereign bonds, the costs of quickly proceeding to consolidation are likely to exceed their expected benefits, so that it is best to let future economic growth lead to a gradual reduction in the public debt-to-GDP ratio (Ostry et al. 2015). This change in attitude parallels the recognition by IMF officials that the public expenditure multiplier is much higher than previously thought, at least when measured in times of a slow-down (Blanchard and Leigh 2013). This means that fiscal austerity policies, in particular reductions in government expenditure, have a much greater negative impact on the economy than what was previously assessed. There has been a complete reappraisal of the values of these income multipliers, with the new measures being in line with those that used to be estimated by Keynesian models prior to the New Classical counter-revolution. This reinforces the irrelevance of the crowding-out effects mentioned earlier.

\section{CONCLUSION}

In this article, I have tried to stress that there is considerable dissatisfaction with the current state of mainstream macroeconomics and with the quasi-dictatorial directive that the only game to be played in town is the adoption of the DSGE model. This 
dissatisfaction arises from economists of all persuasions - heterodox, neo-Austrian and even a number of orthodox authors. The puzzle is: why is it that DSGE models, which are based on calibration while their assumptions are contrary to factual evidence, are still being considered as the nec plus ultra of macroeconomics? The crisis has made a number of economists realize that one cannot adopt a model just because it provides formalized foundations that are consistent with neoclassical microeconomic theory and correspond to the standards advocated by a small group of trend-setting academics, while this model describes an imaginary world. Such a reconsideration means that a number of components of the standard baggage of mainstream economists have to be questioned.

Without going into any detail, it seems clear to me, as Paul Krugman has argued several times, that New Classical economics or what has also come to be known as freshwater economics simply has not survived the test of time. The same applies to what many modern macroeconomists used to consider as compulsory components of any formal theory: the rational expectations hypothesis, the strong or semi-strong version of the efficient market hypothesis, the unbiased efficiency hypothesis in international finance, the assumption of perfect asset substitutability, the NAIRU as a unique (or even time-varying) attractor of the actual rate of unemployment, Barro's Ricardian equivalence theorem, and the idea of expansionary fiscal contractions based on the confidence fairy. The global financial crisis has completely undermined those hypotheses or assumptions, because, as reported for a while on a sidebar of the Financial Times' website, 'the credit crunch has destroyed faith in the free market ideology that has dominated Western economic thinking for a generation'. Economics prides itself on being an empirical science. It cannot entertain these wild assumptions anymore. I just cannot see how models depicting imaginary economies (in contrast to models resulting from simplifications) have any usefulness.

Other mainstream concepts are under threat, in particular in monetary economics. Quickly, once again, one can mention the quantity theory of money, the notion that excess reserves lead to inflation, the money multiplier story and its associated fractional-reserve banking system. Also under threat, in my opinion, is the belief in the usefulness of quantitative easing, the necessity of central-bank independence and even inflation-targeting. It is no longer clear that some inflation rate is the true single target of several central banks; instead, it seems that many of them are just as much concerned, or more concerned, with financial stability, the unemployment rate or the foreign exchange rate. It is difficult to claim that these central banks are still pursuing some kind of Taylor rule. The zero lower bound story on nominal interest rates, although highly popular now, may also be a victim of the winds of change. ${ }^{12}$

Once again, heterodox economists are not the only ones who are appalled at the academic popularity of some mainstream models. Justin Wolfers (2016), who is a former graduate student of Blanchard, when presenting at a session honouring his former supervisor, has given a list of 'things that probably aren't true'. The list resembles the one I had independently compiled a year before, as found above. He lists the following concepts that almost certainly are false: rational expectations, DSGE models, consumption Euler equations, Calvo pricing, New Keynesian Phillips curves, the classical dichotomy. Whereas we were told that DSGE models based on sound microfoundations were good at predictions, Wolfers shows instead that the workhorse of DSGE models has a dismal performance when it comes to one-quarter or four-quarters

12. More details on the winds of change in monetary economics are provided in Lavoie (2015d). 
ahead forecasts of inflation rates and growth rates. There isn't much left to justify the quasi-exclusive use of these models.

Orthodox authors such as Krugman or Wren-Lewis like to claim that the New Keynesian approach, which they often present as the realistic alternative to the hard-core New Classical model, has successfully internalized the zero lower bound and has given space to counter-cyclical fiscal policy, thus implying that there is no need for heterodox alternatives since there is a sufficient amount of pluralism within neoclassical theory. But if we are to believe Wolfers, there isn't much left of all the strands of mainstream macroeconomics, be it freshwater or saltwater macroeconomics. Indeed, checking his list of things that are unlikely to be true, one can only conclude that Wolfers rejects all the essential constructs of the New Keynesian approach. One cannot claim that mainstream economics needs a bit of repair at the seams. New Keynesians pretend that they are making reasonable modifications to the New Classical model; but the latter model, which acts as the base of the New Keynesian model, is pure madness, as claimed by Hope and Soskice (2016). If the foundations are not solid, nor will be the building.

Again using broad brush-strokes, it is clear that some concepts have to be brought back from the limbo in which they have been since the Monetarist and Lucasian theoretical counter-revolution threw away during the mid 1970s to early 1980s what little was left of the Keynesian revolution. In my opinion, with depression economics being back, as Krugman would say, the following ideas have come back into view: the crucial positive role of expansionary fiscal policy and the importance and relevance of fiscal policy at large; the possibility and even necessity of credit controls by the monetary and regulatory authorities - something that used to be supported by post-Keynesian monetary economists and which now seems to be advocated by some neo-Austrian economists; ${ }^{13}$ the need to integrate into a single model the real economy and the financial side, by going beyond the introduction of the target rate of interest, for instance by considering the effects of the stocks of both corporate and household debt, as well as the immediate effects of the additions to these stocks. Two other claims, long made by heterodox authors, are now getting more attention from some international organizations: the favourable effects of controls over foreign capital flows, in particular short-term flows, as recently argued in detail by Gallagher (2014); and the need to consider income distribution as a key component of aggregate demand - a long-time claim of postKeynesian economists - as well as the realization that there is no necessary trade-off between income equality and growth.

The crisis has led to the reconsideration of many dogmas in macroeconomic and monetary theory. Perhaps, more importantly, it has led some researchers at large international organizations to question their entire philosophical stance. Ostry et al. (2016), in an IMF journal devoted to a large readership, wonder whether neoliberal policies have been oversold. They examine two standard neoliberal policies geared to promote long-term growth: first, fiscal austerity, that is, the attempt to reduce fiscal deficits and public debt, notably by reducing the size of government expenditures (the so-called 'expansionary' fiscal consolidation); and, second, the removal of restrictions on the mobility of capital across countries. Their argument is that these two policies did not increase economic growth, and that furthermore they did lead to more income and wealth inequality. The reason is that both of these policies reduce the bargaining power of labour and increase that of the rich and wealthy (Ostry 2015). But there is an additional twist to this story: 'Increased inequality in turn hurts the level and sustainability of growth'

13. The ECB Targeted Long-Term Refinancing Operations (TLTRO) may be perceived as some sort of selective credit control, in this case selective credit inducement. 
(Ostry et al. 2016, p. 39). In particular, free capital mobility increases the probability of a financial crisis and of large output declines, and these in turn are associated with increased income inequality. Thus, these authors conclude that instead of delivering growth, some neoliberal policies have increased inequality, in turn jeopardizing durable expansion' (ibid., p. 38). ${ }^{14}$

Some orthodox economists believe that mainstream economics holds under normal conditions (Richard Koo's yang phase), but that it needs to be modified under zero lower bound conditions or during balance-sheet recessions (Koo's yin phase). Macroeconomic theory needs to be revised both for the yang and the yin phases. Providing new clothes to the Naked Emperor of mainstream economics won't do; the Emperor needs to be dethroned.

\section{REFERENCES}

Ball, L. (2014), 'Long-term damage from the Great Recession in OECD countries', European Journal of Economics and Economic Policies: Intervention, 11(2), 149-160.

Bernanke, B. (2010), 'On the implications of the financial crisis for economics', available at: http://www.federalreserve.gov/newsevents/speech/bernanke20100924a.pdf.

Blanchard, O. (2008), 'The state of macro', NBER working paper 14259, available at: http:// www.nber.org/papers/w14259.pdf.

Blanchard, O. (2014), 'Where dangers lurks', Finance and Development, September, 28-31.

Blanchard, O. (2015), 'Looking forward, looking back', IMF Survey Magazine, 31 August, available at: http://www.imf.org/external/pubs/ft/survey/so/2015/RES083115A.htm.

Blanchard, O. (2016), 'Do DSGE models have a future', Peterson Institute for International Economics, Policy Brief PB 16-11.

Blanchard, O. and D. Leigh (2013), 'Growth forecast errors and fiscal multipliers', American Economic Review, 103(3), 117-120.

Blanchard, O., G. Dell'Aricci and P. Mauro (2010), 'Rethinking macroeconomic policy', IMF Staff Position Note, SPN/10/03, available at: https://www.imf.org/en/Publications/IMF-StaffPosition-Notes/Issues/2016/12/31/Rethinking-Macroeconomic-Policy-23513.

Blanchard, O., E. Cerutti and L. Summers (2015), 'Inflation and activity: two explorations and their monetary implications', NBER Working Paper 21726, available at: http://www.nber. org/papers/w21726.

Blecker, R.A. (2016), 'Finance, distribution and the role of government: heterodox foundations for understanding the crisis', Studies in Political Economy, 97(1), 75-85.

Blinder, A.S. (2014), 'What did we learn from the financial crisis, the Great Recession, and the pathetic recovery?', Griswold Center for Economic Policy Studies, Working Paper No 243.

Borio, C. and W. White (2004), 'Wither monetary and financial stability? The implications of changes in monetary policy regimes', BIS Working Paper No 147.

Buiter, W. (2009), 'The unfortunate uselessness of most "state of the art" academic monetary economics', originally published in the Financial Times, 3 March, now available at: https://mpra.ub.uni-muenchen.de/58407/1/MPRA_paper_58407.pdf.

Carlin, W. and D. Soskice (2015), Macroeconomics, Institutions, Instability, and the Financial System, Oxford: Oxford University Press.

Colander, D. (ed.) (2006), Walrasian Macroeconomics: Beyond the Dynamic Stochastic General Equilibrium Model, Cambridge, UK: Cambridge University Press.

14. If capital mobility reduces the bargaining power of labour, then surely it is likely that free trade agreements have the same negative effect on the capacity of labour organizations to negotiate wages. Thus free trade is also likely to have detrimental effects on income equality and longterm growth. This was recognized by Jonathan Ostry during the question period in a seminar held at the University of Ottawa in the spring of 2016. 
Colander, D. (2010), 'The economics profession, the financial crisis, and method', Journal of Economic Methodology, 17, 419-427.

Colander, D. and C. Rothschild (2009), 'Complexity and macro pedagogy: the complexity vision as a bridge between graduate and undergraduate macro', in G. Fontana and M. Setterfield (eds), Macroeconomic Theory and Macroeconomic Pedagogy, Basingstoke, UK: Palgrave Macmillan, pp. 118-128.

Constâncio, V. (2015), 'Monetary policy and the euro area problem', speech in Frankfurt, 16 November, available at: https://www.ecb.europa.eu/press/key/date/2015/html/sp151116.en. html.

Delong, J.B. and L.H. Summers (2012), 'Fiscal policy in a depressed economy', Brookings Papers in Economic Activity, March(1), 233-297.

Friedman, G. (2016a), 'What would Sanders do? Estimating the economic impact of Sanders' programs', available at: http://www.dollarsandsense.org/What-would-Sanders-do-013016. pdf.

Friedman, G. (2016b), 'Response to the Romers', available at: http://dollarsandsense.org/FriedmanResponse-to-the-Romers.pdf.

Gallagher, K.P. (2014), Ruling Capital, Ithaca, NY: Cornell University Press.

Garcia Duarte, P. (2012): 'Not going away? Microfoundations in the making of a new consensus in macroeconomics', in P. Garcia Duarte and G. Tadeu Lima (eds), Microfoundations Reconsidered: The Relationship of Micro and Macroeconomics in Historical Perspectives, Cheltenham, UK and Northampton, MA: Edward Elgar, pp. 190-237.

Godley, W. (1992), 'Maastricht and all that', London Review of Books, 14(19), 3-4. (Reprinted in M. Lavoie and G. Zezza (eds), The Stock-Flow Consistent Approach: Selected Writings of Wynne Godley, Basingstoke, UK: Palgrave Macmillan, pp. 189-193.)

Goodhart, C.A.E. (2009), 'The continuing muddles of monetary theory: a steadfast refusal to face the facts', in E. Hein, T. Niechoj and E. Stockhammer (eds), Macroeconomic Policies on Shaky Foundations: Whither Mainstream Economics?, Marburg: Metropolis, pp. 351-369.

Hein, E. (2016), 'Secular stagnation of stagnation policy? Steindl after Summers', PSL Quarterly Review, 69(216), 3-47.

Hope, D. and D. Sokice (2016), 'Growth models, varieties of capitalism and macroeconomics', Politics and Society, 44(2), 209-226.

Kaldor, N. (1960), 'Characteristics of economic development', in N. Kaldor, Essays on Economic Stability and Growth, London: Duckworth, pp. 233-242.

Krugman, P. (2009), 'How did economists get it so wrong?', available at: http://www.nytimes. com/2009/09/06/magazine/06Economic-t.html?_r=1\&em=\&pagewanted=print.

Kurz, H.D. (2010), 'On the dismal state of a dismal science', Homo Oeconomicus, 27(3), 1-21.

Lavoie, M. (2010a), 'Are we all Keynesians?', Revista de Economia Politica - Brazilian Journal of Political Economy, 30(2), 189-200.

Lavoie, M. (2010b), 'The possible perverse effects of declining wages', International Journal of Pluralism and Economics Education, 1(3), 260-275.

Lavoie, M. (2012), 'Perspectives for post-Keynesian economics', Review of Political Economy, 24(2), 321-336.

Lavoie, M. (2012/2013), 'Financialization, neo-liberalism and securitization', Journal of Post Keynesian Economics, 35(2), 211-229.

Lavoie, M. (2015a), 'Teaching monetary theory and monetary policy implementation after the crisis', European Journal of Economics and Economic Policies: Intervention, 12(2), 220-228.

Lavoie, M. (2015b), 'Should heterodox economics be taught in or outside economics departments?', International Journal of Pluralism and Economics Education, 6(2), 134-150.

Lavoie, M. (2015c), 'Book review of Carlin and Soskice, macroeconomics, institutions, instability, and the financial system', European Journal of Economics and Economic Policies: Intervention, 12(1), 135-142.

Lavoie, M. (2015d), 'Rethinking monetary policy in light of the crisis', paper presented at the Jornadas Monetarias y Bancarias, Central Bank of the Republic of Argentina, June.

Lavoie, M. (2016), 'Understanding the global financial crisis: contributions of post-Keynesian economics', Studies in Political Economy, 97(1), 57-74. 
Lavoie, M. and M. Seccareccia (2015), 'What even famous mainstream economists miss about the Cambridge capital controversies', available at: https://www.ineteconomics.org/ideaspapers/blog/what-even-famous-mainstream-economists-miss-about-the-cambridge-capitalcontroversies.

León-Ledesma, M.A. and A.P. Thirwall (2002), 'The endogeneity of the natural rate of growth', Cambridge Journal of Economics, 26(4), 441-459.

Lucas, R. (1981), Studies in Business Cycle Theory, Cambridge, MA: MIT Press.

Lucas, R.E. (2003), 'Macroeconomic priorities', American Economic Review, 93(1), 1-14.

Mendoza Bellido, W. (2013), 'J.M. Keynes, neoclassical synthesis, New neoclassical synthesis and the crisis: the current state of macroeconomic theory', Documento de Trabajo No 357, Departamento de Economía, Pontificia Universidad Católica del Perú, available at: http://departamento.pucp.edu.pe/economia/images/documentos/DDD354.pdf.

Mitchell, W. and J. Muysken (2008), Full Employment Abandoned: Shifting Sands and Policy Failures, Cheltenham, UK and Northampton, MA: Edward Elgar.

Ostry, J.D. (2015), 'Inequality and the duration of growth', European Journal of Economics and Economic Policies: Intervention, 12(2), 137-147.

Ostry, J.D., A.R. Gosh and R. Espinoza (2015), 'When should public debt be reduced?', IMF Staff Discussion Note, SDN 15/10.

Ostry, J.D., P. Lougani and D. Furceri (2016), 'Neoliberalism oversold?', Finance and Development, June, 38-41.

Palley, T. (1997), 'European monetary union: an Old Keynesian guide to the issues', Banca Nazionale del Lavoro Quarterly Review, 201(June), 147-164.

Palley, T.A. (2012), From Financial Crisis to Stagnation: The Destruction of Shared Prosperity and the Role of Economics, Cambridge, UK: Cambridge University Press.

Parguez, A. (1999), 'The expected failure of the European Economic and Monetary Union: a false money against the real economy', Eastern Economic Journal, 25(91), 63-76.

Patinkin, D. (1948), 'Flexibility and full employment', American Economic Review, 38(4), 543-564.

Robinson, J. (1956), The Accumulation of Capital, London: Macmillan.

Rolnick, A. (2010), 'Interview with Thomas Sargent', available at: https://www.minneapolisfed. org/publications/the-region/interview-with-thomas-sargent.

Romer, C.D. and D.H. Romer (2016), 'Senator Sanders's proposed policies and economic growth', available at: https://ineteconomics.org/uploads/general/romer-and-romer-evaluationof-friedman1.pdf.

Romer, P. (1999), 'Interview with Paul C. Romer', in B. Snowdon and H. Vane (eds), Conversations with Economists: Interpreting Macroeconomics, Cheltenham, UK and Northampton, MA: Edward Elgar, pp. 292-313.

Romer, P. (2015), 'Mathiness in the theory of economic growth', American Economic Review, 105(5), 89-93.

Romer, P. (2016), 'The trouble with macroeconomics', working paper, available at: https:// paulromer.net/wp-content/uploads/2016/09/WP-Trouble.pdf.

Setterfield, M. (2002), 'Introduction: a dissenter's view of the development of growth theory and the importance of demand-led growth', in M. Setterfield (ed.), The Economics of DemandLed Growth: Challenging the Supply-Led Vision of the Long Run, Cheltenham, UK and Northampton, MA: Edward Elgar, pp. 1-18.

Simonazzi, A. and A. Vianello (1999), 'Liberalizzazione finanziara, moneta unica europea e occupazione', in F.R. Pizzuto (ed.), Globalizzazione, Istituzioni e Coesione Sociale, Cantazaro: Meridiana, pp. 227-253.

Solow, R.M. (2003), 'Dumb and dumber in macroeconomics', address at Joseph Stiglitz's 60th birthday conference, available at: http://economistsview.typepad.com/economistsview/2009/ 08/solow-dumb-and-dumber-in-macroeconomics.html.

Solow, R.M. (2008), 'The state of macroeconomics', Journal of Economic Literature, 22(1), 243-249.

Stanley, T.D. (2004), 'Does unemployment hysteresis falsify the natural rate hypothesis? A meta-regression analysis', Journal of Economic Surveys, 18(4), 589-612. 
Stiglitz, J.E. (2011), 'Rethinking macroeconomics: what failed, and how to repair it', Journal of the European Economic Association, 9(4), 591-645.

Stiglitz, J.E. (2015), 'Reconstructing macroeconomic theory to manage economic policy', in E. Laurent and J. Le Cacheux (eds), Fruitful Economics: Papers in Honor of and by Jean-Paul Fitoussi, Basingstoke, UK: Palgrave Macmillan, pp. 20-49.

Storm, S. and C.W.M. Naastepad (2007), 'It is high time to ditch the NAIRU', Journal of Post Keynesian Economics, 29(4), 531-554.

Summers, L.H. (2014), 'U.S. economic prospects: secular stagnation, hysteresis, and the zero lower bound', Business Economics, 49(2), 65-74.

Summers, L. (2015), 'Reflections on the productivity slowdown', Keynote address at the conference 'Making Sense of the Productivity Slowdown', Peterson Institute for International Economics, available at: http://www.piie.com/publications/papers/transcript-20151116keynote.pdf.

Vergeer, R. and A. Kleinknecht (2010/2011), 'The impact of labor market deregulation on productivity: a panel analysis of 19 OECD countries (1960-2004)', Journal of Post Keynesian Economics, 33(2), 371-407.

White, W. (2009), 'Modern macroeconomics is on the wrong track', Finance and Development, December, $14-18$.

Wilkins, C. (2014), 'Monetary policy and the underwhelming recovery', Remarks at the CFA Society Toronto, available at: http://www.bankofcanada.ca/2014/09/monetary-policy-underwhelming-recovery/.

Wolfers, J. (2016), 'New directions in research and policy', Blanchard-fest celebration, MIT, 4 June, available at: http://users.nber.org/ jwolfers/papers/Comments/Blanchard-fest.pdf.

Wren-Lewis, S. (2016), 'Unravelling the New Classical counter revolution', Review of Keynesian Economics, 4(1), 20-35. 